\title{
A SOIL-DWELLING Pseudomonas SP.593 HARBORING AN EXOGENOUS hrpZ GENE ELICITS A TYPICAL HYPERSENSITIVE RESPONSE IN TOBACCO AND SOYBEAN LEAVES
}

\author{
LONG D., HE H., XIONG M., LI Y., WU W. AND WANG X.* \\ The Faculty of Life Sciences, Hubei University, 368 Youyi Road, Wuchang, Wuhan 430062, PR, China. \\ *Corresponding Author: Email- xgw569@hotmail.com
}

Received: February 16, 2013; Accepted: March 07, 2013

\begin{abstract}
Pseudomonas sp.593 is a soil-dwelling bacterium unable to elicit any hypersensitive response (HR) in tobacco or soybean. The hrpZ gene, encoding an abundant Type III secretion system (T3SS) dependent protein, was cloned from a phytopathogen Pseudomonas syringae pv. syringae Van Hall CFCC 1336. The HrpZ harpin expressed in E. coli was purified to homogeneity, and used to raise polyclonal antiHrpZ rabbit serum. The cloned hrpZ gene was then introduced into the soil bacterium Pseudomonas sp.593 via transformation of the plasmid pMEK-hrpZ. Western blotting and HR assay showed that the hrpZ-transformed Pseudomonas sp.593 was not only able to secret HrpZ harpin but also elicited a strong HR reaction in tobacco and soybean just as $P$. syringae did. In addition, bacterial cells were able to grow and multiply in the HR zone. Our results demonstrate that an avirulent strain can become a virulent-like pathogen, or a pathogen strain can broaden its host range once a single exogenous hrpZ gene cloned from a phytopathogen is introduced into a bacterium displaying phylogenetic diversity.

Keywords- Pseudomonas sp.593, HrpZ harpin, Type III secretion system, Hypersensitive elicitation
\end{abstract}

Citation: Long D., et al. (2013) A Soil-dwelling Pseudomonas sp.593 Harboring an Exogenous hrpZ Gene Elicits a Typical Hypersensitive Response in Tobacco and Soybean Leaves. International Journal of Microbiology Research, ISSN: 0975-5276 \& E-ISSN: 0975-9174, Volume 5, Issue 2, pp.-375-381. DOI : 10.9735/0975-5276.5.2.375-381.

Copyright: Copyright@2013 Long D., et al. This is an open-access article distributed under the terms of the Creative Commons Attribution License, which permits unrestricted use, distribution and reproduction in any medium, provided the original author and source are credited.

\section{Introduction}

A number of Gram-negative bacterial animal and plant pathogens (e.g. Escherichia coli, Salmonella typhimurium, Salmonella enterica, Burkholderia mallei, Shigella flexneri, Yersinia spp, Pseudomonas syringae, Xanthomonas campestris, Ralstonia solanacearum and Erwinia amylovora) depend on the type III secretion system (T3SS) for the full bacterial virulence [1-5]. The T3SS is thought to only express and assemble to appre-ciable levels after the bacterium directly contacts with a eukaryotic host or when the bacterium grows in the hrp-inducing minimal medium [6]. The T3SS pilus, a major part of the secretion ap-paratus, forms a direct conduit between the pathogen and its host and injects T3SS effector proteins directly from the bacterial cell into the cytosol of the host $[7,8]$. The major function of theeffector proteins, delivered into host cells by T3SS, is to suppress the defense response by interfering with signal transduction, which results in cytoskeletal changes or direct cytotoxic effects $[9,10]$. In resistant plants, some of those effector proteins secreted via T3SS induce the hypersensitive response (HR) characterized by local programmed cell death [11] The HrpZ harpin, an abundant T3SS-dependent protein, was isolated and identified as the product of the $h r p Z$ gene in several $P$. syringae pathovars $[12,13]$. This protein is conserved in all the $P$. syringae patho-vars except in pv. tabaci [14], and shares some characteristics with other harpins (eg. HrpF, HrpK and HrpN) found in different Gram-negative phytopathogens, and is also partially homologous with $\mathrm{HrpN}$ [15-17]. It is heat-stable, glycine-rich, lacks cysteine and is secreted to the extracellular space, and is the sole $P$. syringae
T3SS effector that can induce the host defense response outside host cells. The HrpZ harpin is abun-dantly secreted under T3SSinducing conditions, and localized around the HrpA pili during the filament pilus extension and within the plant cell wall region [18].

The HrpZ protein is thought to bind to lipid bi-layers and form ionconducting pores in the host cell membrane, but its function in pathogenesis is still conjectural. The hrpZ mutant has no detectable phenotype in virulence on host plants [19] or in defense induction on nonhost plants [20]. The secretory expression of the hrpZpsph gene in those transgenic plants is able to elicit hypersensitive cell death [21]. Several different activities associated with HrpZ protein in vitro suggested that it could be a multifunctional protein able to interact with several other molecules. For instance, HrpZ is able to insert into patricidal lipid bilayers and to form cation-permeable pores $[19,22]$, harbor a binding site for peptides with a defined consensus sequence and bind proteins of host origin [16]; The peptidebinding activity of HrpZ was localized to a region separate from the region acting as an $\mathrm{HR}$ elicitor in tobacco and parsley [23]. The detailed study found that HrpZ forms dimers or higher order oligomers, and interacts only with phosphatidic acid among 15 different membrane lipids [24]. In addition, HrpZ oligomerization is mainly medi-ated by a region near the C-terminus of the protein, and the same region is also essential for membrane pore formation. Phosphatidic acid binding is mediated by two regions separate in the primary structure. The 24-amino-acid fragment residing in the region indispensable for the oligomerization and pore formation functions of HrpZ is responsible for HR elicitor function, and peptide- 
binding is mediated by a long region near the N-terminus of the protein[24,25] have recently found that $P$. syringae naturally lacking one or more gene loci of the canonical T3SS are ubiquitous in nonagricultural habitats and phylogenetical diverse. It is inevitable to raise a question whether a nonagricultural habitat with phylogenetical diversity can become a virulent phytopathogen once it acquires the related gene from external environment via certain genetic mechanisms. In this study, the hrpZ gene, cloned from a phytopathogen $P$. syringae pv. syringae Van Hall CFCC 1336, was introduced into a soil-dwelling Pseudomonas sp. 593 unable to induce HR in tobacco and soybean. The Pseudomonas sp. 593 strain harboring an exogenous hrpZ gene effectively secreted HrpZ protein, and elicited a typical hypersensitive response in nonhost soybean and tobacco just as the phytopathogen $P$. syringae did. Potential biological significance is also discussed.

\section{Materials and Methods \\ Strains, Plasmids, Primers and Chemicals}

The strains, plasmids and primers used in this study are described in [Table-1]. All reagents for molecular manipulations and DNA marker were purchased from Takara. The DNA gel recovery kit was purchased from Axygen Scientific, Inc., and culture media, antibiotics, inorganic and organic reagents were purchased from Zhong Ke (Shanghai, China).

Table 1- Strains, plasmids and primers used in this study.

\begin{tabular}{|c|c|c|}
\hline $\begin{array}{l}\text { Strain, plasmid and primer } \\
\text { Strains }\end{array}$ & Characteristics & Source \\
\hline DH5a & $\begin{array}{l}F-, \varphi 80 d l a c Z \Delta M 15, \Delta(l a c Z Y A-a r g F) U 169, \text { deoR, recA1, endA1, hsdR17(rk-,mk+ ), phoA, } \\
\text { supE44, } \lambda \text {-, thi-1, gyrA96, relA1 }\end{array}$ & Invitrogen \\
\hline BL21(DE3) )pLysS & F-, ompT, hsdSB(rB-, mB-), gal(גcl857, ind1, Sam7nin5, LacUV5-T7 gene1), dcm(DE3), pLysS & Stratagene \\
\hline Pseudomonas.sp 593 & $a m p^{r}, \mathrm{~cm}^{r}$ & Lab collection \\
\hline Pseudomonas syringae pv. syringae Van Hall CFCC 1336 & & CFCC* \\
\hline \multicolumn{3}{|l|}{ Plasmids } \\
\hline pMD18-T & ampr, ColE1 & Takara \\
\hline pET23a & T7-promoter, ampr, his-Tag, T7-teminator & Novagen \\
\hline ptac85 & ampr , tac promoter & Marsh P [39] \\
\hline PTRG & tet', ColE1 & Agilent technologies \\
\hline pMEKm12 & ampr, tac promoter, ColE1, ori 1606 & Gift from Dr. Cheng \\
\hline pMEK-hrpZ & ampr, tet $r$ ColE1, ori ${ }_{1606}$, tac promoter & This study \\
\hline \multicolumn{3}{|l|}{ Primers } \\
\hline hrpZ-F & 5'-AGGATCATATGCAGAGTCTCAGTCTTAACA-3' & This study \\
\hline hrpZ-R1 & 5'AGTGTCGACCTATCAGGCCGCGGCCTGATT-3' & This study \\
\hline hrpZ-R2 & 5'-AGTGAATTCCTATCAGGCCGCGGCCTGATT-3' & This study \\
\hline hrpZGF & 5'-KPCKOLMCTKWAOOAOTCGWA -3' ^ & This study \\
\hline hrpZGR & 5'-TWCTWCAYCTTKAAYAGLTMWTTW -3' ^ & This study \\
\hline tet-F & 5-AGTCCTGCAGGACCCGCAAGAATTGATTGGGC-3' & This study \\
\hline tet-R & 5'-AGTCAAGCTTGCTATTATCCGCTCACAATTCC-3' & This study \\
\hline hrcC-F & 5'- ggatccatgcgcaaggccttgatg-3' & This study \\
\hline hrcC-R & 5'- aagctttggctttgctcctcgga-3' & This study \\
\hline
\end{tabular}

\section{Gene Cloning and Expression}

Based on the hrpZ sequence of $P$. syringae pv. syringae B728a in Genbank (NC-007005.1), the forward and reverse primers hrpZ-F and hrpZ-R were designed and synthesized by Invitrogen, Shanghai. Total DNA of $P$. syringae pv. syringae Van Hall CFCC 1336 was extracted using standard protocol described in Molecular Cloning [26], and used as template. PCR was performed using the following cycle parameters: $5 \mathrm{~min}$. at $94^{\circ} \mathrm{C}$, followed by 30 cycles of $30 \mathrm{sec}$. at $94^{\circ} \mathrm{C}, 1.5 \mathrm{~min}$. at $65^{\circ} \mathrm{C}, 1 \mathrm{~min}$. at $72^{\circ} \mathrm{C}$, and a final incubation at $72^{\circ} \mathrm{C}$ for $5 \mathrm{~min}$. The amplified DNA fragments were separated through $1 \%$ agarose electrophoresis, and the desired DNA fragment $(1 \mathrm{~kb})$ was recovered using DNA gel recovery kit. The recovered DNA fragment was ligated with pMD18-T vector by incubating the mixture at $16^{\circ} \mathrm{C}$ for $4 \mathrm{Hrs}$., and then the ligation mixture was transformed directly into $\mathrm{E}$. coli $\mathrm{DH} 5 \mathrm{a}$ by using the $\mathrm{CaCl}_{2}$ method [26]. The transformants ware selected using LB plates supplemented with $100 \mathrm{mgml}$ ampicillin. Positive colonies were confirmed by PCR using two primers hrpZ-F and hrpZ-R1, and the cloned hrpZ gene was sequenced by Shanghai Sangon Biotech.

The recombinant pMD18-T plasmid DNA containing the cloned hrpZ gene was digested with Ndel and Sall, and then the hrpZ gene fragment was recovered using a DNA gel recovery kit. The hrpZ gene was inserted into the expression vector pET23a at the Ndel and Sall sites to form recombinant plasmid pET23a-hrpZ. The
pET23a-hrpZ plasmid was then transformed into $E$. coli BL21 (DE3) pLysS by using the $\mathrm{CaCl}_{2}$ method [26]. Positive transformants were screened on LB plates containing $100 \mathrm{mg} / \mathrm{ml}$ ampicillin. Expression of the hrpZ gene in E. coli BL21 (DE3) pLysS transformants growing at $25^{\circ} \mathrm{C}$ in LB broth supplemented with $100 \mathrm{mg} / \mathrm{ml}$ ampicillin was induced by adding IPTG to a final concentration of $0.5 \mathrm{mM}$ for $6 \mathrm{Hrs}$. Bacterial cells were harvested by centrifugation at $4,000 \mathrm{rpm}$ at $4^{\circ}$ $C$, the cell pellet was suspended in $50 \mathrm{mM}$ phosphate buffer ( $\mathrm{pH} 7.4)$, and the crude extract was finally prepared via centrifugation at $12,000 \mathrm{rpm}$ at $4^{\circ} \mathrm{C}$ after sonication.

\section{Protein Purification}

Since the HrpZ protein contains a 6'His-tag at its C-terminus, Niaffinity chromatography was employed for purification. The crude extract was clarified by centrifugation at $12,000 \mathrm{rpm}$ for $15 \mathrm{~min}$. at $4^{\circ} \mathrm{C}$. The Ni-column was equilibrated with $50 \mathrm{mM}$ phosphate buffer $(\mathrm{pH} 7.4)$, and then washed and gradient eluted with $50 \mathrm{mM}$ phosphate buffer $(\mathrm{pH} 7.4)$ containing $0-200 \mathrm{mM}$ imidazole after the protein sample was loaded. Protein concentration was estimated by measuring the absorbance at a wavelength of $280 \mathrm{~nm}$ and calculated by

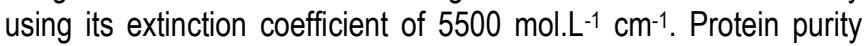
was routinely monitored by SDS-PAGE, after staining with Coomassie blue R250. The HrpZ protein was purified to homogeneity, and $25 \mathrm{mg}$ pure protein was obtained from $1 \mathrm{~L}$ of bacterial culture through one step of purification. The biological activity of the puri- 
fied HrpZ was confirmed by HR assay.

\section{Polyclonal Antibody Preparation}

Polyclonal antibody was generated to the HrpZ harpin based on the method described by Vinogradov, et al. [27] and He, et al. [28]. The HrpZ protein clarified by centrifugation at $12,000 \mathrm{rpm}$ at $4^{\circ} \mathrm{C}$ for 30 min., and then $0.5 \mathrm{mg}$ of the clarified protein was mixed with CFA (complete Freund's adjuvant) (1:1 v/v). Anti-HrpZ serum was raised in rabbits by i.h injection of $100 \mathrm{ml}$ of the protein-CFA mixture each time. After 6 injections, three rabbits were sacrificed and their sera were collected. Antibody titer for anti-HrpZ serum was monitored by ELISA according to the method described by Pantophlet, et al. [29].

\section{Plasmid Construction and Transformation}

Construction of the plasmid pMEK-hrpZ is shown in [Fig-1]. The soil bacterium Pseudomonas sp. 593 is capable of growing in a medium containing low dosage of kanamycin $(\sim 30 \mathrm{mg} / \mathrm{ml})$. To obtain positive transformants easily, the tetr fragment $(1.5 \mathrm{~kb})$ with a promoter was first amplified by PCR using tet- $F$ and tet- $R$ as a primer pair and pTRG plasmid DNA as template, and then inserted into pMEKm12 at pstl and HindllI sites to form a recombinant plasmid pMEKm12 tetr. The activity of pMEKm12-tetr against tetracycline was examined by transforming the plasmid into $E$. coli $\mathrm{DH} 5 \mathrm{a}$ and growing the bacterium in on an LB plate containing $30 \mathrm{mg} / \mathrm{ml}$ tetracycline. Then the $h r p Z$ gene $(1 \mathrm{~kb})$, cloned from $P$. syringae pv. syringae Van Hall CFCC 1336 by using the primers pcs-F and pcs-R2, was inserted into the plasmid pMEKm12-tetr at Ndel and EcoRl sites to generate a recombinant plasmid named as pMEK-hrpZ. All molecular manipulations were done according to standard protocols [26].

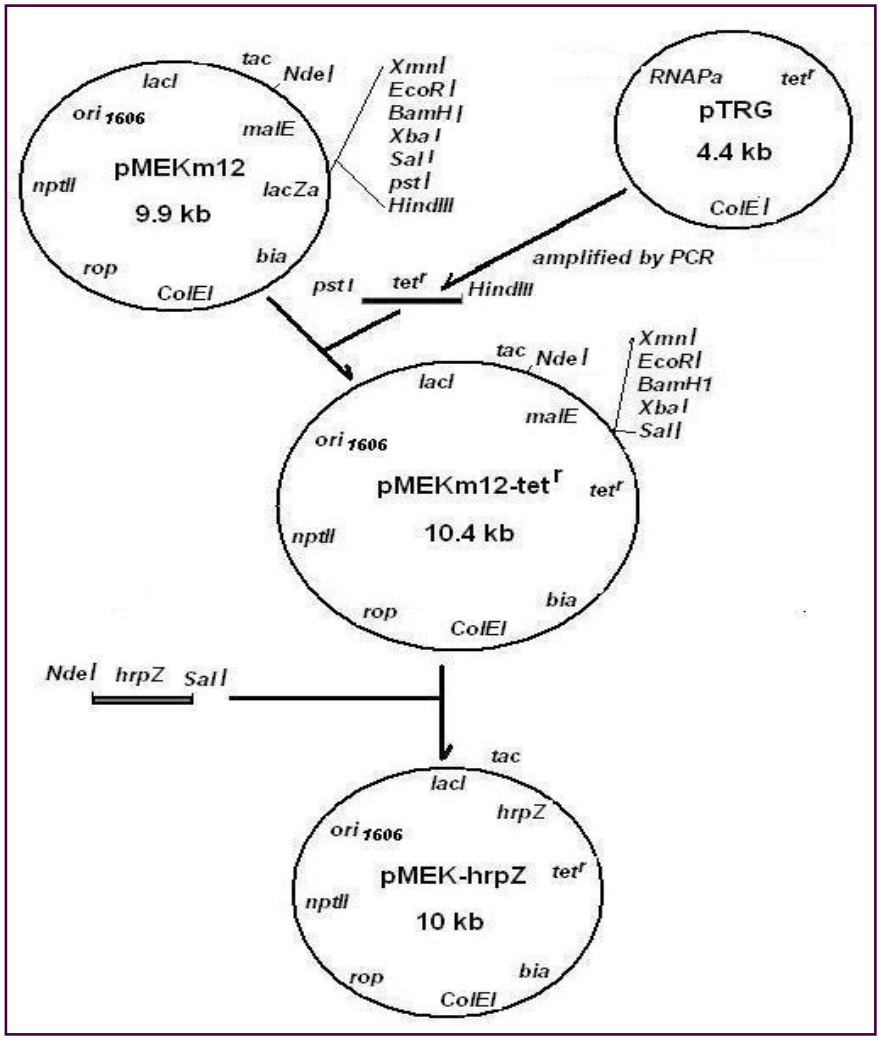

Fig. 1- Construction of the expression vector pMEK-hrpZ

Transformation of Pseudomonas sp. 593 was performed according to the methods described by Solaiman [30]. Bacterial cells grown in $\mathrm{LB}$ broth to logarithmic phase $\left(\mathrm{OD}_{600}=0.6\right)$ were collected and pre- cooled on ice for $30 \mathrm{~min}$., and then washed 3 times by centrifugation at $4^{\circ} \mathrm{C}$ with pre-cooled $100 \mathrm{ml} 300 \mathrm{mM}$ sucrose. The competent cells were re-suspended in $2 \mathrm{ml} 300 \mathrm{mM}$ sucrose, and stored at $-80^{\circ}$ C. The plasmid pMEK-hrpZ was transformed into the strain Pseudomonas sp. 593 by electroporation (Electroporator 2510, Eppendorf). Positive colonies were screened by spreading the transformed cells on LB plates supplemented with $30 \mathrm{mg} / \mathrm{ml}$ tetracycline and incubating at $37^{\circ} \mathrm{C}$ overnight.

\section{Secretion Test and Immunoblot Analysis}

The strain Pseudomonas sp. 593 and the transformant containing pMEK-hrpZ were grown to late-exponential phase in $25 \mathrm{ml}$ hrpinducing minimal medium $(50 \mathrm{mM}$ potassium phosphate, $7.6 \mathrm{mM}$ $\left(\mathrm{NH}_{4}\right)_{2} \mathrm{SO}_{4}, 1.7 \mathrm{mM} \mathrm{MgCl}_{2}, 1.7 \mathrm{mM} \mathrm{NaC1}, 10 \mathrm{mM}$ fructose and mannitol [14] and induced by adding $0.5 \mathrm{mM}$ IPTG at $37^{\circ} \mathrm{C}$. Bacterial cultures were centrifuged at $6,000 \mathrm{rpm}$ at $4^{\circ} \mathrm{C}$ for $15 \mathrm{~min}$., the pellets were resuspended in $50 \mathrm{mM}$ phosphate buffer $(\mathrm{pH} 7.4)$ and washed once with the same buffer to remove any medium residue. Bacterial cells were broken by sonication, and crude extracts were prepared as described above. Bacterial medium solutions obtained from the first centrifugation were centrifuged again at 12,000 rpm at $4^{\circ} \mathrm{C}$ for $20 \mathrm{~min}$. in order to remove any bacterial residue. The proteins in the supernant were precipitated with $5 \%$ trichloroacetic acid, washed with acetone and dissolved in $5 \mathrm{mM} \mathrm{MgCl}_{2}$ as described by Preston, et al. [31]. Protein concentration was determined using the Bradford method [32].Cytoplasmic and membrane proteins were prepared according to the methods reported previously [26,33]. All proteins were separated by SDS-PAGE, and then transferred to Immobilon-P transfer membranes (Millipore) according to the standard procedure [26].

The HrpZ harpin or HrcC protein was recognized with rabbit polyclonal antisera raised to the purified $\mathrm{HrpZ}$ or HrcC encoded by $h r p Z$ or hrcC gene of $P$. syringae pv. syringae Van Hall CFCC 1336. Goat-anti-rabbit IgG alkaline phosphate conjugate (Sigma) was used as the secondary antibody. Membrane-bound secondary antibodies were visualized with BCIP/NBT tablets (Sigma).

\section{HR assay}

Based on the method reported previously [13,34], tobacco (Nicotiana tabacum) and soybean (Glycine max) plants were grown to the 6-8 leaf stage in a climatic chamber at $25^{\circ} \mathrm{C}$ with a $14 \mathrm{Hrs}$. photoperiod and $70-90 \%$ humidity. The purified HrpZ protein, the Pseudomonas sp. 593 cells transformed with the plasmid pMEKhrpZ, and the mixture of the HrpZ protein and Pseudomonas sp. 593 cells were respectively infiltrated onto the abaxial surfaces of plant leaves using a No. 5 latex stopper with a hole designed to fit tightly around a $0.5 \mathrm{ml}$ syringe, thus permitting thumb pressure on the other side of the leaf to provide a tight seal. Pseudomonas sp. 593 cells and $5 \mathrm{mM} \mathrm{MgCl}_{2}$ were used as control. In each inoculum, $5 \mathrm{mg} \mathrm{HrpZ}$ protein or $3^{\prime} 10^{6}$ bacterial cells dissolved or suspended in $10 \mathrm{ml} 5 \mathrm{mM} \mathrm{MgCl}_{2}$ was applied. All bacterial cells were harvested by centrifugation, washed twice with $5 \mathrm{mM} \mathrm{MgCl}_{2}$ and suspended in $5 \mathrm{mM} \mathrm{MgCl}_{2}$ after growth in LB broth containing $100 \mathrm{mgml}$ ampicillin to an $\mathrm{OD}_{600}$ value of 0.2 . The plants were observed over 3 days at $25^{\circ} \mathrm{C}$ for development of hypersensitive response.

\section{Bacterial Counting}

Each inoculum zone of the plant leaves was scooped out with a sterile punch within 3 days postinoculation, and then suspended in $1 \mathrm{ml}$ PBS (pH7.2). Bacterial cells were released into the solution by 
shaking on a shaker at room temperature for $20 \mathrm{~min}$. A serial 10 'dilution was performed with PBS (pH7.2), and the standard plate count method was employed to count bacteria. LB plates containing $100 \mathrm{mg} / \mathrm{ml}$ ampicillin were used for the bacterial cells from the spots of control groups (eg. HrpZ protein, $5 \mathrm{mM} \mathrm{MgCl}_{2}$ and Pseudomonas sp. 593), and the LB plates containing $100 \mathrm{mg} / \mathrm{ml}$ ampicillin and $30 \mathrm{mg} / \mathrm{ml}$ tetracycline for Pseudomonas.sp 593 transformed with the plasmid pMEK-hrpZ. Colony-forming units (CFUs) were counted from triplicates of each dilution, and the number of bacterial cells per milliliter was calculated according to the following formula. Number of bacteria/ml = (number of colonies (CFU) / (dilution'amount plated)

\section{Results}

The Product of the hrpZ Gene Cloned from $P$. syringae pv. syringae Van Hall CFCC 1336 Functions as a HrpZ Harpin

A 1047 bp DNA segment was amplified via PCR in which hrpZ-F, hrpZ-R and the genomic DNA of Pseudomonas syringae pv. syringae Van Hall CFCC 1336 were respectively used as primers and template, and the program TRANSLATE (www. expasy.org) gave it a 1026 bp ORF encoding 341 amino acids [Fig-2]

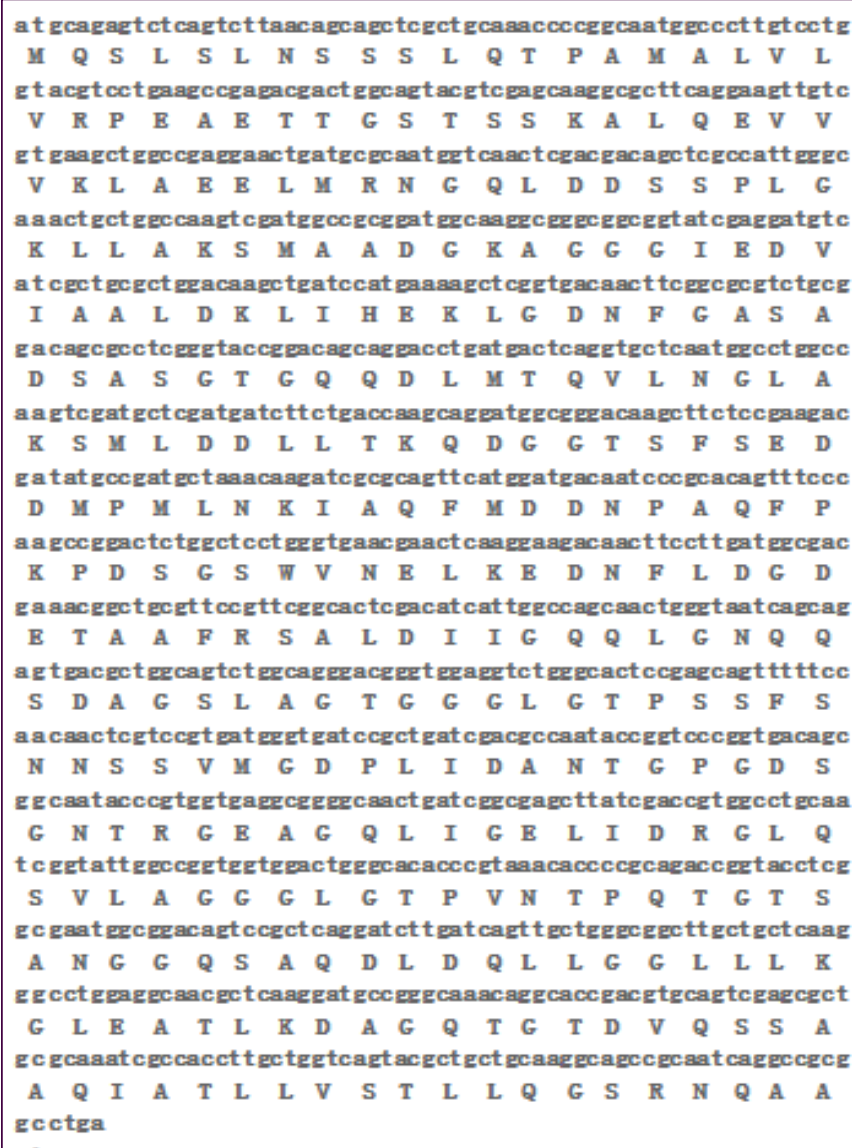

Fig. 2- DNA sequence of the hrpZ gene cloned from Pseudomonas syringae pv.syringae Van Hall CFCC 1336 and the deduced amino acid sequence

Theoretical calculation gave the deduced protein an apparent molecular weight of $34.7 \mathrm{kD}$ with an isoelectric point of 4.2 . Amino acid sequence comparison revealed that the deduced protein shows strong homology to the HrpZ of Pseudomonas syringae pv. syringae (ABQ883651) with an identity of $99.71 \%$. Only one amino acid is different at the position 335, where a threonine residue (Thr) in the HrpZ of $P$ s syringae pv. syringae is replaced by a serine residue (Ser) in the deduced protein. Based on the method of Kyte and Doolittle [35], hydropathic calculation for the deduced protein gave a grand average of hydropathicity of -0.247 , indicating that this protein is hydrophilic. Analysis of subcellular localization by PSORTb (www.psort.org) predicted that it is an extracellular protein with a localization score of 10 . All parameters obtained from the deduced protein are consistent with those for HrpZ harpins encoded by the hrpZ genes of $P$. syringae pv. syringae in Genbank, suggesting that the ORF cloned from the genomic DNA of $P$. syringae $p v$. syringae Van Hall CFCC 1336 appears to encode a HrpZ harpin. The cloned hrpZ gene was inserted into an expression vector pET23a to form a recombinant plasmid $\mathrm{pET} 23 \mathrm{a}-\mathrm{hrpZ}$, and its expression was controlled under a T7 promoter. The pET23a-hrpZ plasmid was then introduced into $E$. coli BL21 (DE3) pLysS. The hrpZ gene in E. coli was expressed at $25^{\circ} \mathrm{C}$ for $6 \mathrm{Hrs}$. and induced by adding $0.5 \mathrm{mM}$ IPTG. [Fig-3a] shows an abundant HrpZ expression as a soluble form in E. coli. Since a 6'his-tag was fused at the C-terminus, the HrpZ protein was purified by using Ni-affinity chromatography. The protein was finally purified to homogeneity [Fig-3b].

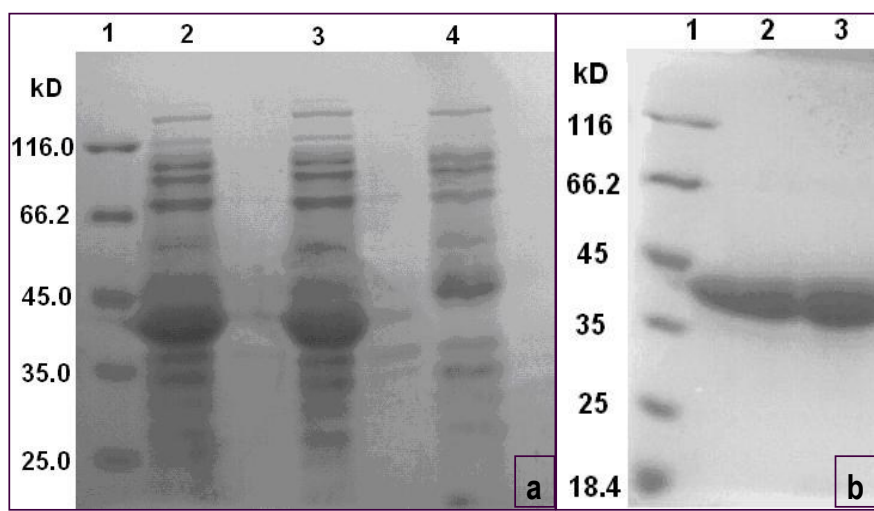

Fig. 3- 10\% SDS-PAGE gels showing the expression product of the hrpZ gene cloned from Pseudomonas syringae pv.syringae Van Hall CFCC 1336 and protein purification. (a) the product of the hrpZ gene expressed in E. coli. Lane 1: protein standard; lane.2 and 3: the crude extracts obtained from two positive transformants; and lane.4: the crude extract of the transformant containing pET23a plasmid as control. (b) the HrpZ protein purified by Ni-affinity chromatography. Lane.1: protein standard; lane 2 and 3: overloaded pure HrpZ protein

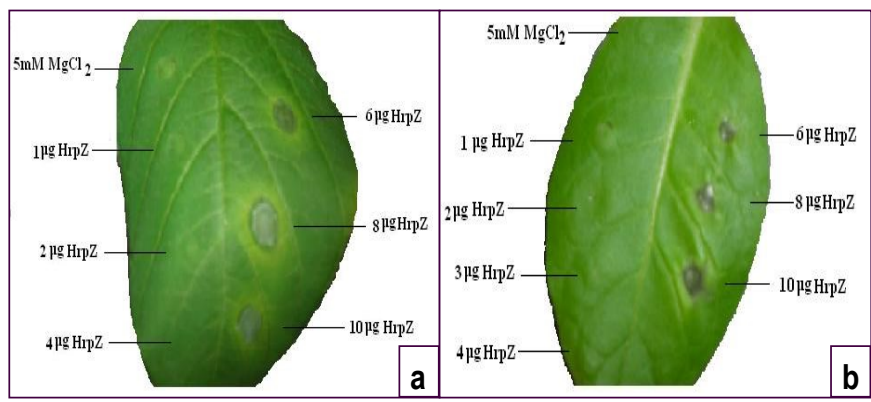

Fig. 4- Tobacco and soybean leaves infiltrated with different concentrations of the purified HrpZ. (a) soybean leaf, and (b) tobacco leaf. Each experiment was repeated three times by using three different leaves under the same condition. $10 \mathrm{ml}$ sample was applied in each inoculum, and the results were observed at 3 days postinoculation. 
To verify whether the purified protein was the product of the $h r p Z$ gene, the purified protein dissolved in $5 \mathrm{mM} \mathrm{MgCl}_{2}$ was infiltrated into both tobacco and soybean leaves to elicit HR. As shown in [Fig -4], hypersensitive confluent necrosis was noticeably observed when more than $4 \mathrm{mg} \mathrm{HrpZ}$ protein was used, and enhanced with the increase of protein concentrations. HR elicitation by the purified protein at both tobacco and soybean leaves demonstrates again that the $h r p Z$ gene cloned from $P$. syringae pv. syringae Van Hall CFCC 1336 indeed functions as a HrpZ harpin.

Soil Bacterium Pseudomonas sp. 593 does not Elicit Hypersensitive Responses in Tobacco and Soybean Leaves

Pseudomonas sp. 593 was previously isolated from soil for other research purposes in our laboratory $[36,37]$. Sequence analysis of 16S rRNA gene revealed that this soil bacterium belongs to Pseudomonas genus, but further classification has not been done. BLAST showed $99 \%$ homology among the 16S rRNA gene sequences of Pseudomonas sp. 593, P. nitroreducens IAM 1439 and $P$. knackmussii B13. In contrast, only less than $95 \%$ homology is exhibited between 16S rRNA gene sequences of Pseudomonas sp. 593 and $P$. syringae, indicating that the two bacteria may perhaps have a more distant phylogeneic relationship. Unlike $P$. syringae $p v$. syringae, Pseudomonas sp. 593 did not infect tobacco and soybean or elicit any hypersensitive response of two plants when its cells were inoculated to tobacco or soybean leaves [Fig-5].

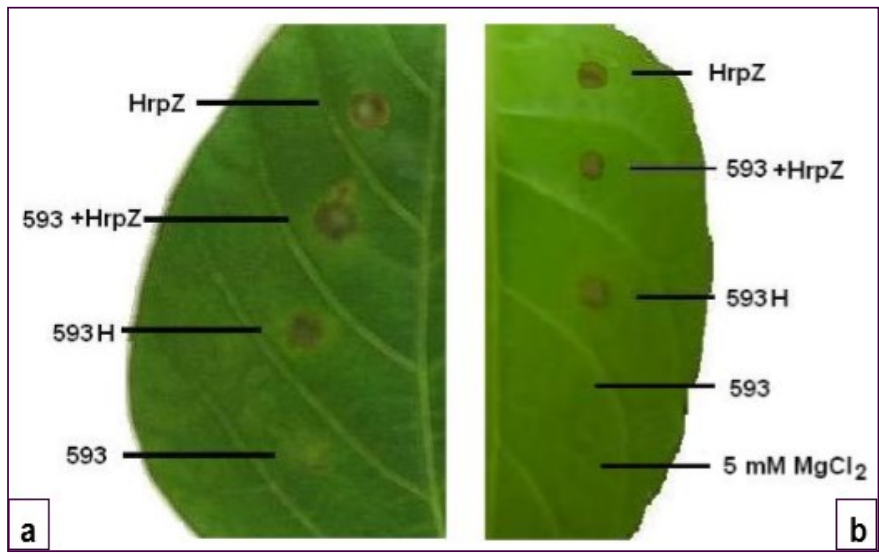

Fig. 5- HR elicitation of tobacco and soybean leaves by the HrpZ harpin and bacterial cells at 3 days postinoculation. (a) soybean leaf, and (b) tobacco leaf. 10ml sample was applied in each inoculum, protein amount was $5 \mathrm{mg}$, and bacterial cells were $10^{6}$. Each experiment was repeated three times by using three different leaves under the same condition. The results were observed at 3 days postinoculation. HrpZ: the purified HrpZ protein; 593: Pseudomonas.sp 593; 593+HrpZ: Pseudomonas.sp 593 cells mixed with the HrpZ protein; 593H: Pseudomonas.sp 593H cells.

Obviously, Pseudomonas sp. 593 was a HR- strain incapable of inducing a hypersensitive reaction in tobacco and soybean, implying that it might lack at least one gene in the canonical hrp/hrc locus or the associated conserved effector locus because those gene loci are necessary for function of T3SS. HrpZ is one of those important virulence factors in T3SS. Hence, hrpZ-F and hrpZ-R specific for cloning the $h r p Z$ gene of $P$. syringae $p v$. syringae were used as a primer pair, and PCR was performed to amplify the $h r p Z$ gene from the genomic DNA of Pseudomonas sp. 593. No DNA band was observed on $0.8 \%$ agarose gel (data not shown). The degenerate primers hrpZGF and hrpZGR, designed based on the conserved amino acid sequences of HrpZ proteins of Pseudomonas species in the database, were also used in PCR. Different from the control strain P. syringae pv. syringae Van Hall CFCC 1336, no DNA band was detected in Pseudomonas sp. 593 (data not shown). To further examine whether the soil bacterium has HrpZ protein, we used the polyclonal antibody against the HrpZ protein to hybridize with both cytoplamic and secretory proteins of Pseudomonas sp. 593. Western blotting did not show any hybridization signal [Fig-6a]. All those results suggest that the soil bacterium Pseudomonas sp. 593 may not have a hrpZ gene such as existing in many Pseudomonas plant pathogens. We also investigated if Pseudomonas sp. 593 contains $\mathrm{HrCC}$ protein which is a major component of T3SS in bacterial membrane. Hybridization between the membrane extract of the soil bacterium and the polyclonal antibody against the $\mathrm{HrcC}$ protein of P. syringae pv. syringae Van Hall CFCC 1336 gave a strong band in a nitrocellulose blotting membrane [Fig-6b]. When the primers hrcC-F and hrcC-R specific for cloning hrcC gene of $P$. syringae $p v$. syringae Van Hall CFCC 1336 were used, hrcC gene was sucessfuly amplified by PCR from the genomic DNA of Pseudomonas sp. 593 , and its corresponding amino acid sequence shared $99 \%$ homology with that for $P$. syringae $p v$. syringae Van Hall CFCC 1336 (data not shown). These results imply that the soil bacterium Pseudomonas sp. 593 may perhaps hold a T3SS.

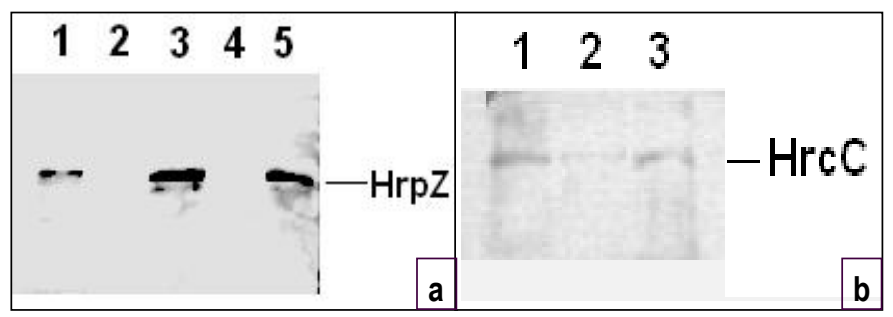

Fig. 6- Western blot analysis. (a) hybridization of the anti-HrpZ polyclonal rabbit serum with the proteins prepared separately from bacterial cells and the cell-free culture. Lane 1: the purified HrpZ; lane 2: the crude extract of Pseudomonas.sp 593 cells; lane 3: the crude extract of Pseudomonas.sp 593H cells; lane 4: the cell-free culture in which Pseudomonas.sp 593 grew; lane 5: the cell-free culture in which the Pseudomonas.sp 593H grew. (b) hybridization of the anti$\mathrm{HrcC}$ polyclonal rabbit serum to the membrane proteins extracted from Pseudomonas.sp 593 strain. Lane 1: the purified HrcC; lane 23: the outer membrane extract of Pseudomonas.sp 593. The amount of protein loaded in lane 2 was $60 \%$ less than that in lane 3

\section{Soil Bacterium Pseudomonas sp. 593 Transformants Contain- ing Exogenous hrpZ Gene are Capable of Secreting HrpZ harpin}

Given that our speculation described above was correct, Pseudomonas sp. 593 containing an exogenous hrpZ gene could use its type III pathway to secrete HrpZ harpin from cytoplasm to the medium. We inserted the $h r p Z$ gene cloned from $P$. syringae pv. syringae Van Hall CFCC 1336 into a expression vector pMEKm12tett to form a recombinant plasmid pMEK-hrpZ as shown in [Fig-1].

The recombinant plasmid was then introduced into Pseudomonas sp. 593 cells, and positive colonies were isolated and confirmed by PCR. The positive transformant containing pMEK-hrpZ was named as Pseudomonas sp. $593 \mathrm{H}$. A single colony of Pseudomonas sp. $593 \mathrm{H}$ was inoculated into the hrp-inducing minimal medium supplemented with $0.5 \%$ choline, and then incubated at $37^{\circ} \mathrm{C}$. The expression of $h r p Z$ gene was induced by adding IPTG to a final concentration of $0.5 \mathrm{mM}$. After $12 \mathrm{Hrs}$., bacterial cells and the medium were separated by centrifugation, and then the cytoplasmic and secreted 
proteins were respectively prepared from the cell pellet and the cellfree medium. Finally, the cytoplasmic and secreted proteins wee separately hybridized with the anti-HrpZ polyclonal antibody. As shown in [Fig-6a], both proteins, prepared from the cytoplasmic extract and the cell-free medium of positive transformants, gave a strong band, but those extracted from the control strain Pseudomonas sp. 593 did not give any signal. This result clearly demonstrates that Pseudomonas sp. 593H harboring the exogenous hrpZ gene is able to secret HrpZ protein effectively.

\section{Soil Bacterium Pseudomonas sp. 593 Transformant Harboring an Exogenous hrpZ Gene is Capable of Eliciting Hypersensi- tive Responses}

Effective secretion of HrpZ harpin implies that Pseudomonas sp. $593 \mathrm{H}$ could have an ability to infect plants. Pseudomonas sp. $593 \mathrm{H}$ was grown in the hrp-inducing minimal medium containing $0.5 \%$ choline and $0.5 \mathrm{mM}$ IPTG at $37^{\circ} \mathrm{C}$ for $12 \mathrm{Hrs}$. Bacterial cells were collected by centrifugation, and then resuspended in $5 \mathrm{mM} \mathrm{MgCl}$. The suspended cells ware immediately inoculated onto the surface of both tobacco and soybean leaves. Meanwhile, Pseudomonas sp. 593, Pseudomonas sp. 593 transformed with pMEKm12-tetr, Pseudomonas sp. 593 plus the purified HrpZ protein, the purified $\mathrm{HrpZ}$ protein alone, and $5 \mathrm{mM} \mathrm{MgCl}_{2}$ were used as controls. [Fig-5] shows all results observed in 3 days postinoculation of tobacco and soybean leaves. As expected, Pseudomonas sp. 593 (3'106 cells), and $5 \mathrm{mM} \mathrm{MgCl}_{2}$ did not display any activity of $\mathrm{HR}$ elicitation. The Pseudomonas sp. 593 transformed with pMEKm12-tetr (3'106 cells) did not show any visible HR elicitation (data not shown). The purified HrpZ protein (5mg), Pseudomonas sp. 593 (3'106 cells) mixed with the HrpZ (5 mg) clearly showed HR elicitation. The HR symptom, caused by Pseudomonas sp. 593 mixed with the HrpZ, could result from the HrpZ harpin, because Pseudomonas sp. 593 alone did not induce any HR reaction. Interestingly, the Pseudomonas sp. $593 \mathrm{H}\left(3^{\prime} 10^{6}\right.$ cells) elicited a typical HR in both tobacco and soybean leaves of inoculum [Fig-5]. This result again verifies that the soil bacterium Pseudomonas sp. $593 \mathrm{H}$ is able to secret HrpZ harpin. The HR specificity of Pseudomonas sp. $593 \mathrm{H}$ clearly comes from the HrpZ harpin.

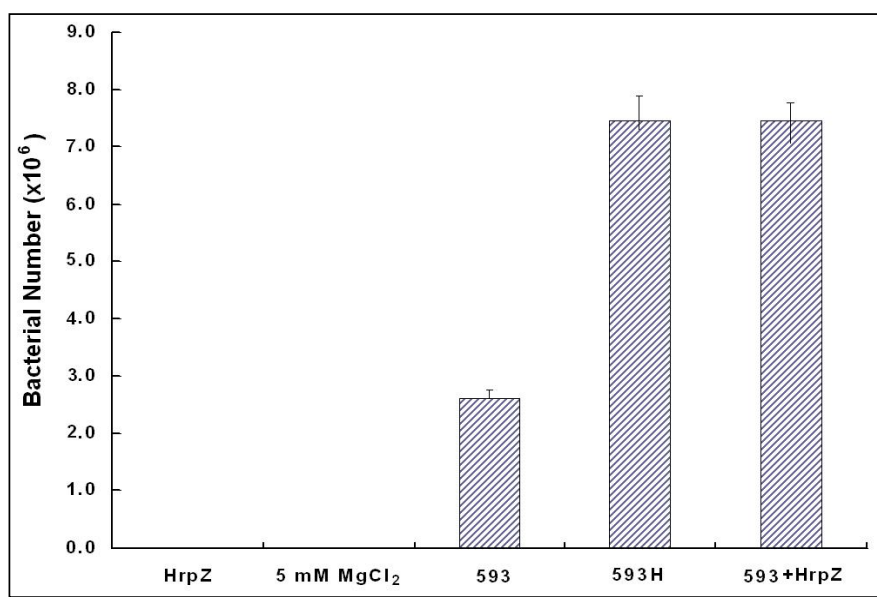

Fig. 7- Bacterial numbers counting from inoculum zones of tobacco leaves as shown in [Fig-5]. The standard plate count method was used as described in experimental section. Bacterial cells were collected within 3 days postinoculation. All data were calculated from three independent experiments. HrpZ: the purified HrpZ protein; 593: Pseudomonas.sp 593; 593+HrpZ: Pseudomonas.sp 593 mixed with the HrpZ protein; 593H: Pseudomonas.sp 593H.
Bacterial survival and multiplication in HR zones were also investigated via viable bacterial cell count, and the result was summarized in [Fig-7]. As expected, no viable bacterial cell was detected in those regions infiltrated with the solvent $\left(5 \mathrm{M} \mathrm{MgCl}_{2}\right)$ or the hrpZ protein. The zone infiltrated with Pseudomonas sp. 593 gave 2.6 $10^{6}$ cells, similar to the bacterial amount $\left(3^{\prime} 10^{6}\right.$ cells) used initially for infiltration. This soil bacterium could survive on the surface of tobacco leaves in 3 days postinoculation although it did not elicit any HR reaction. In the zones infiltrated with Pseudomonas sp. 593 plus the HrpZ protein or Pseudomonas sp. 593, viable bacterial count gave $7.5^{\prime} 10^{6}$ cells. Obviously, bacterial numbers in both cases increased 2.5 fold as compared with that for initial infiltration, suggesting that the bacterial cells not only survived but also multiplied slowly in the HR zones. Bacterial multiplication indicated that bacterial cells could utilize the nutrition released from the cationpermeable pores of plant cells $[19,22]$ after tobacco leaves were infiltrated with either the purified HrpZ or the HrpZ secreted by Pseudomonas sp. $593 \mathrm{H}$.

\section{Discussion}

The strain Pseudomonas sp. 593 was isolated from soil in our laboratory. BLAST search (http://blast.ncbi.nlm.nih.gov) revealed that approximate 1501 bp DNA sequence of Pseudomonas sp. 593 16S rRNA gene was $398 \%$ identical to those of Pseudomonas nitroreducens strain IAM 1439 (99\%), Pseudomonas knackmussii strain B13 (99\%), Pseudomonas citronellolis strain DSM 50332 (98\%), Pseudomonas delhiensis strain RLD-1 (98\%) and Pseudomonas jinjuensis strain Pss 26 (98\%). P. syringae pv. syringae did not appear in the $95 \%$ similarity list of $16 \mathrm{~S}$ rRNA gene sequences. Based on sequence analysis of $16 \mathrm{~S}$ rRNA gene, Pseudomonas sp. 593 and $P$. syringae $p v$. syringae belong to the same Pseudomonas genus but may be different species. Strong hybridization signal between the membrane proteins of Pseudomonas sp. 593 and the anti-HrcC polyclonal antibody and effective secretion of HrpZ harpin by Pseudomonas sp. $593 \mathrm{H}$ illustrate that this soil bacterium man hold an intact type III secretory apparatus in its cell membrane, because the $\mathrm{HrcC}$ protein is a major component of type III secretory apparatus. Without HrcC in outer embrane, the hrcC mutant accumulated the HrpZ in periplasmic space as a membrane-bound protein although the mutant expressed HrpZ protein as effectively as the wild type [20].

Thus, we postulated that Pseudomonas sp. 593 harboring the plasmid pMEK-hrpZ could elicit plant HR reaction. Our results demonstrate that Pseudomonas sp. $593 \mathrm{H}$ indeed elicits a typical $\mathrm{HR}$ in both tobacco and soybean foliage. Recently, Morris's group [25] has reported that $P$. syringae naturally lacking the canonical type III secretion system are ubiquitous in nonagricultural habitats, and display phylogenetic diversity. In the natural environment, gene transfer from a bacterial strain to another may happen via different genetic mechanisms, such as bacterial conjugation, DNA transformation or transfection in intraspecies of $P$. syringae. It is also possible that one or more gene transfers could happen in interspecies of Pseudomonas via certain genetic mechanisms. Once a hrpZ- soil bacterium holding a T3SS acquires a $h r p Z$ gene from external environments, it can become a virulent pathogen. Even though Pseudomonas sp. 593 does not elicit any HR reaction in tobacco and soybean, we can not rule out the possibility that it is a pathogen able to infect other plants yet, because some $P$. syringae strains lacking any one gene of the canonical T3SS still cause severe symptoms [25]. When Pseudomonas sp. 593 unable to infect tobac- 
co and soybean acquired the $h r p Z$ gene of $P$. syringae pv. syringae, it not only expressed and secreted HrpZ harpin but also induced a typical HR reaction in tobacco and soybean. These results demonstrate that an avirulent strain can become a virulent-like pathogen, or a pathogen strain can broaden its host range once it obtains hrpZ gene from external environments. Nevertheless, further investigation specific for gene transfer in intraspecies and interspecies of bacteria in nature is still required. HrpZ harpin is thought to be very useful in agriculture for inducing plant resistance against various viral or bacterial phytopathogens [38]. Pavli, et al. [38] have recently reported that the HrpZ enhanced resistance to Rhizomaania disease in transgenic tobacco and sugar beet, which suggests that phytobacterial harpins may now offer an opportunity for generating broad-spectrum resistance in plants. Nevertheless, potential health harm caused by transgenic plants has caused public concern. Successful expression and secretion of HrpZ harpin by the soil-dwelling Pseudomonas sp. 593 harboring a hrpZ gene may perhaps provide another insight into enhancing plant resistance against phytopathogens using the phytobacterial harpins. The avirulent soil bacterium harboring a harpin gene is sowed around plant roots, and then plant resistance will be induced via infiltration of the harpin secreted by the avirulent soil bacterium into plant roots. The correlative studies are in progress in our laboratory.

\section{Acknowledgements}

We thank Prof. Paul C. Engel of Conway Institute, University College Dublin, Ireland for help with the review of the manuscript and language check. This work was supported by the grant form the National Nature Science Foundation of China (30970076 to XGW).

\section{References}

[1] Bretz J.R., Hutcheson S.W. (2004) Infect. Immun., 72, 36973705.

[2] Espinosa A., and Alfano J.R. (2004) Cell Microbiol., 6, 10271040.

[3] He S.Y., Nomura K., Whittam T.S. (2004) Biochim. Biophys. Acta., 1694, 181-206.

[4] Hueck C. (1998) Microbiol. Mol. Biol. Rev., 62, 379-433.

[5] Zaharik M.L., Gruenheid S, Perrin A.J., Finlay B.B. (2002) Int. J. Med. Microbiol., 291, 593-603.

[6] He S.Y. (1998) Annu. Rev. Phytopathol., 36, 363-392.

[7] Dobrindt U., Hochhut B., Hentschel U., Hacher J. (2004) Nat. Rev. Microbiol., 2, 414-424.

[8] Guttman D.S., Gropp S.J., Morgan R.L., and Wang P.W. (2006) Mol. Biol. Evol., 23, 2342-2354.

[9] Grant S.R., Fisher E.J., Chang J.H., Mole B.M. and Dangl J.L. (2006) Annu. Rev. Microbiol., 60, 425-449.

[10]Guo M., Tian F., Wamboldt Y. and Alfano J.R. (2009) Mol. Plant -Microbe. Interact., 22, 1069-1080.

[11]Mur L.A.J., Kenton P., Lloyd A.J., Ougham H. and Prats E. (2008) J. Exp. Bot., 59, 501-520.

[12]Alfano J.R. and Collmer A. (1997) J. Bacteriol., 179, 5655-5662.

[13]Musa A.R., Minardi P. and Mazzucchi U. (2001) Antonie van Leeuwenhoek, 79, 61-71.

[14]Taguchi F., Tanaka R. and Kinoshita S. (2001) J. Gen. Plant Pathol., 67, 116-123.

[15]Buttner D., Nennstiel D., Klusener B. and Bonas U. (2002) J.
Bacteriol., 184, 2389-2398.

[16]Li C.M., Haapalainen M., Lee J., Nurnberger T., Romantschuk M. and Taira S. (2005) Mol. Plant-Microbe Interact., 18, 60-66.

[17]Petnicki-Ocwieja T., van Dijk K. and Alfano J.R. (2005) J. Bacteriol., 187, 649-663.

[18]Brown I.R., Mansfield J.W., Taira S., Roine E. and Romantschuk M. (2001) Mol. Plant Microbe Interact., 14, 394-404.

[19]Lee J., Klüsener B., Tsiamis G., Stevens C., Neyt C., Tampakaki A.P., Panopoulos N.J., Nöller J., Weiler E.W., Cornelis G.R., Mansfield J.W. and Nürnberger T. (2001b) Proc. Natl. Acad. Sci., USA, 98, 289-294.

[20]Charkowski A.O., Huang H.C. and Collmer A. (1997) J. Bacteriol., 179, 3866-3874.

[21]Tampakaki A.P., Panopoulos N.J. (2000) Mol. Plant Microbe Interact., 13, 366-74.

[22]Lee J., Klessig D.F. and Nurnberger T. (2001a) Plant Cell, 13, 1079-1093.

[23]Engelhardt S., Lee J., Gabler Y., Kemmerling B., Haapalainen M., Li C.M., Wei Z., Keller H., Joosten M., Taira S. and Nurnberger T. (2009) Plant J., 57, 706-717.

[24]Haapalain M., Engelhardt S., Kufner I., Li C.M., Nurnberger T., Lee J., Romantschuk M. and Taira S. (2011) Mol. Plant Pathol., 12, 151-166.

[25]Diallo M.D., Monteil C.L., Vinatzer B.A., Clarke C.R., Glaux C., Guilbaud C., Desbiez C. and Morris C.E. (2012) The ISME Journal, 6, 1325-1335.

[26]Sambrook J., Fritsch E., and Maniatis T. (2001) Molecular Cloning: a Laboratory Manual, Cold Spring Harbor, New York.

[27]Vinogradov E.V., Pantophlet R., Dijkshoorn L., Brade L., Holst O., and Brade H. (1996) Eur. J. Biochem., 239, 602-610.

[28]He S.Y., huang H.C. and Collmer A. (1993) Cell, 73, 12551266.

[29]Pantophlet R., Brade L., Dijkshoorn L. and Brade H. (1998) J. Clin. Microbiol., 36, 1245-1250.

[30]Solaiman D.K.Y. (1998) Biotechnology Techniques, 12, 829832.

[31]Preston G., Deng W.L., Huang H.C. and Collmer A. (1998) J. Bacteriol., 180, 4532-4537.

[32]Bradoford M. (1976) Biochem., 72, 248-254.

[33]Xu C., Wang S., Ren H., Lin X., Wu L., Peng X. (2005) Proteomics, 5, 3142-3152.

[34]Gopalan S., Bauer D.W., Alfano J.R., Loniello A.O., He S.Y., and Collmer A. (1996) Plant Cell, 8, 1095-1105.

[35]Kyte J., Doolittle R.F. (1982) J. Mol. Biol., 157, 105-132.

[36]He H., Wu B., Xiong M., Li Y., Wu W., Wang X.G. (2011) Can J. Microbiol., 57, 785-794.

[37]Xiong M., Wu B., He H., Li Y. and Wang X.G. (2011) Sin, 51, 747-755.

[38]Pavli O.I., Kelaidi G.I., Tampakaki A.P. and Skaracis G.N. (2011) Plos One, 6(3), e17306.

[39]Marsh P. (1986) Nucleic Acids Res., 14, 3603.

[40]Alfano J.R., Bauer D.W., Milos T.M. and Collmer A. (1996) Mol. Microbiol., 19, 715-728. 